\title{
A Framework for Preemption Analysis
}

The decisions of the Supreme Court in cases involving preemption of state law by federal statutes have often produced considerable confusion ${ }^{1}$ and criticism. ${ }^{2}$ This Note argues that those decisions can be rationalized according to the protection afforded by the state law in question. Laws that protect the people inside state borders from physical injury have received the greatest deference from the Court. Laws that protect the people inside state borders from other dangers have received less deference. State laws that purport to protect people mostly outside state borders have received little deference. Recognition of these categories, as they are set out in this Note, can assist courts as they deal with future preemption cases.

\section{Categories for Preemption Analysis}

It is useful to distinguish four possible relationships between national and state laws, which may conveniently be called "express preemption," "express saving," "prohibition of dutiful conduct," and "hindrance." Express preemption and express saving are direct relationships between national and state law. Express preemption occurs when a national statute expressly forbids state regulation of a certain type or expressly requires that national regulation be exclusive. Express saving is present when a national statute expressly forbids courts to preempt state laws. Prohibition of dutiful conduct and hindrance are indirect relationships, which involve more complex interactions between state and national law. Prohibition of dutiful conduct is present when state law requires someone to breach duties imposed by national law. Hindrance occurs when state law interferes with opportunities created by national law, or with the performance of federal duties.

Three possible relations between state law and the people it protects may also be distinguished. "Extraterritorial protection" occurs when a state law protects people mostly outside state borders. "Territorial protection" occurs when a state law protects a group of people who are

1. See, e.g., note 29 infra (contradictory inferences drawn by Court from presence of "comprehensive" national requirements); notes 31 \& 76 infra (contradictory inferences drawn by Court from congressional failure to require an action).

2. See, c.g., Hirsch, Toward a New J'iew of Federal Preemption, 1972 U. ILL. L.F. 515, 545-17 (activist Court has not conformed to congressional expectations); Note, The Preemption Doclrine: Shifting Perspectives on Federalism and the Burger Court, 75 Colum. L. REv. 623, 639 (1975) (Court has sometimes shown too little concern for state interests). 
mostly inside state borders. "Territorial protection of vital interests" occurs when state law protects people mostly inside state borders from physical injury.

These distinctions provide a framework for explaining the Court's preemption cases. Extraterritorial protection has been preempted by a mere showing of some hindrance. In contrast, territorial protection has been preempted only if express preemption or prohibition of dutiful conduct is present or if the state law substantially hinders conduct essential to the achievement of the overall objective of a federal statute. Territorial protection of vital interests has been on a still higher tier, because physical injury is not usually deemed necessary to achieve a national statutory purpose. Thus only express preemption or prohibition of dutiful conduct are sure to preempt state statutes that protect vital interests inside state borders.

\section{A. Express Preemption}

Express preemption occurs when a national statute expressly forbids the type of state regulation in question or expressly requires that national regulation of the subject in question be exclusive. Express preemption clauses typically command that "no state shall adopt" certain requirements or that "no [requirements of a particular kind] shall be imposed" by any state. ${ }^{3}$ The statutory command must be clear and unambiguous $^{4}$ and must have the force of national law; even unambiguous declarations in the legislative history of a national statute have not sufficed. ${ }^{5}$ Statutory preemption clauses eliminate the need

3. See, e.g., 42 U.S.C.A. $\$ 7543$ (West 1978) (preempting regulation of automobile emissions); 42 U.S.C. $\$ 1973$ (Supp. V 1975) (preempting literacy tests).

4. E.g., Florida Lime \& Avocado Growers, Inc. v. Paul, 373 U.S. 132, 147 (1963); H.P. Welch Co. v. New Hampshire, 306 U.S. 79, 85 (1939); cf. Murdock v. City of Memphis, 87 U.S. (20 Wall.) 590, 618-19 (1875) (Congress must use "plain, unmistakable language" to change longstanding practice that denies Supreme Court review of state court determinations of state questions); Tribe, Intergovernmental Immunities in Litigalion, Taxation, and Regulation: Separation of Powers Issues In Controversies about Federalism, 89 HARv. L. REV. 682, 691-97 (1976) (Congress must make "clear statement" to deprive states of sovereign immunity).

5. For example, a House committee report on a national labor law declares that "by the Labor Act Congress preempts the field ... insofar as commerce within the meaning of the Act is concerned." H.R. REP. No. 245, 80th Cong., Ist Sess. 44 (1947). Despite this declaration the Court held that state regulation of certain strike activities regulated by this national law "cannot fairly be said to be pre-empted without a clearer declaration of congressional policy than we find here." UAW v. Russell, 356 U.S. 634, 646 (1958). Legislative history was similarly ineffectual in, e.g., New York Dep't of Social Servs. v. Dublino, 413 U.S. 405, 417 (1973). See Brief of Appellees at 21, 22; Brief of National Welfare Rights Organization as Amicus Curiae at 39-43.

The Court has thus refused to treat legislative commentary as an authoritative command. See pp. 382-84 \& note 121 infra. It has, however, sometimes used legislative commentary to support the preemption of state laws substantially hindering conduct necessary to give effect to a national statute. E.g., Street, Elec. Ry. \& Motor Coach Em- 
for judicial inquiry into the overall purposes of national statutes and into the effect of state laws on the implementation of those statutes. ${ }^{6}$

In many cases Congress has expressly forbidden state attempts at territorial protection. ${ }^{7}$ For example, it used an express preemption clause to prohibit state voting laws that imposed literacy tests. ${ }^{8}$ It may even forbid state laws that protect vital interests. Recent lower court decisions have, for example, held that national statutes expressly preempted state or local attempts to protect the lives of people from the conduct of participants in interstate transportation. ${ }^{\circ}$ Similarly, the Supreme Court itself recently acknowledged that Congress has nearly absolute "power over areas of private endeavor, even when its exercise may pre-empt express state-law determinations contrary to the result which has commended itself to the collective wisdom of Congress."10 By enacting an express preemption clause, Congress can clearly command courts to find that state law is preempted.

\section{B. Express Saving}

Express saving is present when a national statute expressly forbids a preemptive interpretation of national law and this command is applicable to the state law in question. Saving clauses typically command

ployees Div. 998 v. Wisconsin Employment Relations Bd., 340 U.S. 383, 397-98 (1951) (peaceful conduct of labor organization; House report quoted); see pp. 382-87 infra (explaining inference of such hindrance). Legislative history was used in the same way in Guss v. Utah Labor Relations Bd., 353 U.S. I, 9-10 (1957), a case in which the Court preempted state law in order to protect the jurisdiction of the NLRB. See pp. 387-88 infra. But the Court's use of legislative history was criticized as mistaken and its holding was partially overruled by Congress. See Hirsch, supra note 2, at 546-47 \& n.132. Two years after Guss, the Court admitted that congressional guidance on labor preemption was unclear and did not attempt to support its holding by use of legislative history. See San Diego Bldg. Trades Council v. Garmon, 359 U.S. 236, 238-46 (1959).

Very recently the Court has again used legislative history to support preemption in Ray v. Atlantic Richfield Co., 435 U.S. 151,174 (1978) (quoting House Report). In Ray, howerer, special circumstances were present to support preemption. See pp. $380-81$ infra.

6. Determination of express precmption is therefore simpler than the determination of the degree to which state laws hinder achievement of a national statutory objective. See pp. $382-88$ infra.

7. See, e.g., Jones v. Rath Packing Co., 430 U.S. 519, 530-32 (1977) (clause forbidding state standard different from federal standard violated by state law prohibiting package weight variations caused by "moisture loss during the course of good distribution practice"); Railway Employes' Dcp't r. Hanson, 351 U.S. 225, 229 (1956) (clause commanding that parties be permitted to make union security agreements "notwithstanding any other provisions" of state law violated by state law prohibiting union security agreements).

8. 42 U.S.C. $\$ 1973$ (Supp. V 1975) (prohibiting use of literacy tests to deny voting rights); see South Carolina v. Katzenbach, 383 U.S. 301 (1966) (applying this clause).

9. Exxon Corp. v. City of N.Y., 548 F.2d 1088 (2d Cir. 1977) (express preemption of municipal air quality ordinance); Donelon v. New Orleans Terminal Co., 474 F.2d 1108 (5th Cir.), cert. denied, 414 U.S. 855 (1973) (express preemption of municipal safety standards). But see, e.g., Chrysler Corp. v. Tofany, 419 F.2d 499 (2d Cir. 1969) (construing precmption clause narrowly to avoid preempting state safety law).

10. National League of Cities v. Usery, 426 U.S. 833,840 (1976) (dictum). 
that "nothing [herein] shall be construed as preempting" certain state laws or that "nothing [herein] shall be construed as authorizing" conduct forbidden by state law. ${ }^{11}$ Like preemption clauses, saving clauses restrict the sphere of judicial inquiry. If a national statute expressly saves certain state laws, courts have followed this command even if it appears inconsistent with the overall purpose of the statute and even if the state law forbids the exercise of opportunities expressly granted by the national law. ${ }^{12}$ The Court, however, has not yet construed a saving clause to apply to state laws forbidding the performance of national duties. ${ }^{13}$

\section{Prohibition of Dutiful Conduct}

Prohibition of dutiful conduct occurs when national law expressly imposes a duty to undertake certain conduct and state law expressly forbids performance of this duty. These facts have established a ra-

11. See, e.g., 33 U.S.C. $\$ 1321(0)(2)$ (Supp. V 1975) (saving state oil tanker liability laws); 29 U.S.C. $\$ 164(\mathrm{~b})(1970)$ (saving state laws that prohibit contracts making union membership condition of employment).

12. A good example is the regulation of labor unions. With the objective of fostering collective bargaining, national law grants workers opportunities to organize in labor unions and specifically authorizes the negotiation of union security agreements. 29 U.S.C. $\$ \S 151,157,158(a)(3)$ (1970). Yet state prohibitions of union security agreements are expressly saved, 29 U.S.C. $\$ 164(b)(1970)$, and have been upheld by the Court despite apparent conflict with the national statutory objective. See Retail Clerks Local 1625 v. Schermerhorn, 375 U.S. 96, 103 (1963) ("There is thus conflict . . . [here] but it is a conflict sanctioned by Congress with directions to give the right of way to state laws....")

By forbidding courts to preempt certain state laws, a savings clause implicitly permits preemption of other state laws. It is often argued that this implicit permission is a congressional mandate to preempt the state laws that are not expressly saved. See, e.g., California v. Zook, 336 U.S. 725, $755-57$ (1949) (Burton, J., dissenting); Brief of AFL.CIO as Amicus Curiae at 35-36, Retail Clerks Local 1625 v. Schermerhorn, 373 U.S. 746 (1963); Brief of Respondent Board of Trade at 21-24, Rice v. Board of Trade, 331 U.S. 247 (1947). But in each of the three cases cited, this argument was rejected, as the Court upheld the state laws in question. In Schermerhorn, the Court construed the saving clause broadly to apply to the state laws in question. 373 U.S. at 751-54, 757. In Zook, the Court admitted that the state law was excluded from the saving clause, but nonetheless upheld it. 336 U.S. at 732, 737. In Rice, the Court admitted that the state law was excluded from the saving clause, but still used this clause as "intrinsic evidence" to justify upholding the state law in question. 331 U.S. at 255.

Not until 1978 did a litigant arguing the implied preemptive effect of saving clauses succeed in the Supreme Court. See Ray v. Atlantic Richfield Co., 435 U.S. 151 (1978). In rejecting a state limit on oil tanker size, the Court noted that federal law regulated this subject and that the federal statute authorized higher state standards " 'for structures only," thus impliedly preempting higher state standards for vessels. Id. at 174. The earlier Rice-Schermerhorn line of cases was not brought to the attention of the Court in Ray. See Brief of Appellants at 34-35.

13. In a case in which state law forbade compliance with the Federal Power Commission's requirements for river diversion, the Court construed a saving clause as inapplicable to the law, thus allowing preemption to "take its natural course." First Iowa Hydro-Elec. Coop. v. FPC, 328 U.S. 152, 166-67, 176 (1946); see SEC v. National Sec., Inc., 393 U.S. 453, 463 (1969) (stressing that state laws to which McCarran-Ferguson Act saving clause applies do not forbid performance of national duties). 
tionale for preemption. By imposing express duties to perform certain acts, a national statute indicates that these acts are necessary to achieve its overall purpose. ${ }^{14}$ Even if the duty is imposed only on persons to whom the national government has granted licenses or other forms of largesse (and who could therefore avoid the impossibility of dual compliance by giving up the federal largesse), the performance of the national duty has been deemed necessary to achieve the overall purpose of the statute. ${ }^{15}$ The performance of duties imposed by federal agencies rather than by statute, however, has not been accepted as necessary to the statutory purpose without an inquiry into the statutory authority of the agency involved. ${ }^{16}$ In any case, the fact that states expressly forbid such conduct eliminates the need for judicial inquiry into whether state law in some indirect way substantially hinders it.

The presence of a prohibition of dutiful conduct has often preempted state attempts at territorial protection, whether the national command was directed to private parties, ${ }^{17}$ federal executive officers, ${ }^{18}$ federal and state courts, ${ }^{10}$ or state administrators. ${ }^{20}$ National statutes

14. Cf. pp. 385.86 infra (describing process of determining necessity in absence of statutory command).

15. For example, the grant of a commercial broadcasting license carries with it the statutory duty to broadcast replies to political messages. 47 U.S.C. $\$ 315$ (Supp. V 1975). Therefore states may not prohibit reply broadcasts, "the very conduct the [national] statute demands." Farmers Educ. \&. Coop. Union v. WDAY, Inc., 360 U.S. 525, 531 (1959). Similarly, the grant of federal funds carries with it an obligation to distribute those funds to all persons designated by Congress, despite state prohibitions against distribution. E.g., Townsend v. Swank, 404 U.S. 282 (1971). Federal agencies may also impose duties conditioned on receipt of benefits. E.g., First-Iowa Hydro Elec. Coop. v. FPC, 328 U.S. 152, 162, 166, 168 (1946) (diversion of river as condition for grant of permission to build dam).

16. For example, in First-Iowa Hydro Elec. Coop. v. FPC, 328 U.S. 152 (1946), the FPC had imposed a requirement of river diversion. State law prohibited diversion of the river. Before preempting the state law, the Court examined the national statute and the facts, in essence reviewing the FPC's interpretation of the national statutory objective and of the consequent necessity for river diversion. 328 U.S. at 162, 166-74, $180 \&$ n.23. For a case in which the Court's revicw of agency action did not lead to preemption, see Regents of Univ. Sys. v. Carroll, 338 U.S. 586, 591-93, 600-02 (1950) (despite FCC's conditional requirement of nullification of contract, state court can require performance of contract); cf. Organized Village of Kake v. Egan, 369 U.S. 60, 63, 76 (1962) (agency lacks authority to permit fishing forbidden by state law).

17. See, e.g., Schwegmann Bros. v. Calvert Distillers Corp., 341 U.S. 384 (1951).

18. See, e.g., Johnson v. Maryland, 254 U.S. 51, 55-56 (1920).

19. See, e.g., Davis v. Elmira Sav. Bank, 161 U.S. 275 (1896) (national law forbade court to give preferences in distribution of assets of bankrupt; state law required court to give preference). In federal common law cases, a federal court both imposes and performs a national duty. See, e.g., Clearfield Trust Co. v. United States, 318 U.S. 363 (1942) (state law forbade court to recognize claim when bank given untimely notice; federal common law required court to recognize claim of United States, which gave untimely notice to bank).

20. See, e.g., California v. Taylor, 353 U.S. 553 (1956) (duties imposed by Railway Labor Act are binding on state administrators in position of employers of railroad workers). 
have similarly required state administrators to distribute national funds to needy people, thus preempting state limitations on such distributions. ${ }^{21}$

Even state laws protecting vital interests may be preempted if they prohibit performance of national duties. For example, no state may protect the lives of its citizens by commanding national officers to breach their national duty in order to retain custody of persons charged with crime. In barring such state protection, Ableman $v$. Booth ${ }^{22}$ and Tarble's Case ${ }^{23}$ both emphasized the fact that federal courts provided an alternative means of protecting the lives of these persons. ${ }^{24}$

Nevertheless, a national statute can require the violation of state laws without providing national protection for the people deprived of the benefit of state laws. For example, state civil service laws sometimes require state administrators to pay no more than a certain wage. To protect the economic interests of state employees, a national statute might command state administrators to raise wages without providing funds to do so. ${ }^{25}$ The state employees in question might work in agencies that protect the lives of people inside the state. If so, by

21. See, e.g., Townsend v. Swank, 404 U.S. 282, 285 (1971) (state law forbade state administrators to give aid for dependent children to college students; national law required administrators to give AFDC payments to all eligible individuals, and defined "dependent child" to include college students). See generally Dam, The American Fiscal Constitution, 44 U. CHI. L. REv. 271 (1977).

22. 62 U.S. (21 How.) 506 (1858).

23. 80 U.S. (13 Wall.) 397 (1872).

24. See Ableman v. Booth, 62 U.S. (21 How.) 506, 513, 520-23 (1858); Tarble's Case, 80 U.S. (13 Wall.) 397, 411 (1872). For a discussion stressing the importance of state courts, and questioning whether Congress could deprive them of the ability to protect persons lives without providing an alternative, federal means of protection, see P. BAtor, $P$. Mishkin, D. Shapiro \& H. Wechsler, Hart and Wechsler's The Federal Courts aNd THE FEDERAL Systex 359-60, 428 (2d ed. 1973) [hereinafter cited as Hart \& WECHSLER].

The Court may also require alternative federal protection for other important human values. For example, fedcral protection against economic exploitation was apparently not present in Merrill Lynch, Pierce, Fenner \& Smith v. Ware, 414 U.S. 117 (1973). Prohibition of dutiful conduct was present, as the petitioner noted:

Section 229 of the California Labor Code prohibits arbitration of wage disputes between employer and employee ... unless arbitration is required by a collective bargaining agreement. In contrast, Rule 347(b) of the New York Stock Exchange, promulgated under section 6 of the Securities Exchange Act of 1934, requires arbitration of employment disputes between member firms and their employees.

Brief for Petitioner at 11 .

The petitioner also noted that the formulation of rules such as Rule 347(b) was a "statutory duty" of the Exchange. Id. at 16-22. But the Court noted that this rule was not subject to SEC review or modification. 414 U.S. at 134-35. The Court was persuaded that preemption was not "necessary to the furtherance of congressional aims and objectives." Id. at 126-27. The Court therefore upheld the state law "to protect the worker from the exploitative employer." Id. at 131 .

25. Thus this law would differ from the national law in, e.g., Townsend v. Swank, 404 U.S. 282 (1971). See note 15 supra. 
forcing a reduction in the work force, the national command might substantially reduce the protection that states can give to the lives of people, ${ }^{28}$ and the national statute might not provide any alternative national organization to protect these people. ${ }^{27}$ Thus an overall reduction in the protection given to vital interests might be a necessary consequence of enforcing national law in this case. ${ }^{28}$

\section{Hindrance}

Hindrance is present when national law leaves opportunities free of restriction or restricts opportunities by imposing duties, and state law increases the difficulty of taking these opportunities or of performing these duties. Unlike express preemption cases, hindrance cases do not involve a national statutory command forbidding states to regulate. In hindrance cases, as in cases of prohibition of dutiful conduct, preemption has been a function of the relations between national law, state law, and certain conduct.

Conduct can be related to national law by regulation or by nonregulation. National law may regulate conduct by imposing duties. When these duties are most numerous, national regulation has been termed "comprehensive." 29 The Court has sometimes referred to

26. Because the national law regulates the internal relations of state agencies, it would affect each state citizen only indirectly, and only in common with all members of the public inside the state. Therefore even if a private person were deprived of fire or police protection as an indirect result of this national statute, such a private individual would probably lack standing to challenge it. See United States v. Richardson, 418 U.S. 166, 176-78 (1974). But see Choper, The Scope of Nalional Power Vis à Vis the States: The Dispensability of Judicial Review, 86 Yale L.J. 1552, 1558-59 \& n.27 (1977) (individual rights claims are "primary and independent" of claims relating to restriction of state protective abilities).

27. Thus the national statute would differ from the statute in, e.g., Tarble's Case, 80 U.S. (13 Wall.) 397, 411 (1872) (federal courts available to issue habeas corpus). But cf. Prigg v. Pennsylvania, 41 U.S. (16 Pet.) 539 (1842) (state law forbade anyone to aid recapture of fugitive from slavery; national statute required magistrates to aid return of fugitives to slave state, and did not provide alternative national protection for life and liberty of fugitives).

28. Yet judicial enforcement of such a national law may not be inevitable. See National League of Cities v. Usery, 426 U.S. 833 (1976) (attempts by Congress to prescribe minimum wages and maximum hours for state employees held unconstitutional); cf. note 79 infra (constitutional questions involved in preemption cases).

29. It is often argued that "comprehensive" or "pervasive" national regulation leaves no room for state regulation. See, e.g., Brief of Respondents at 8-9, 23, DeCanas v. Bica, 424 U.S. 351 (1976); Brief of the United States as Amicus Curiae at 5, 7-23, Head v. New Mexico Bd. of Examiners, 374 U.S. 424 (1963); Hirsch, supra note 2, at 530-31, 548-51; Note, supra note 2, at $625,633-37$ \& n.64. This argument has often failed. See, e.g., DeCanas v. Bica, 424 U.S. 351, 356 (1976); Head v. New Mexico Bd. of Examiners, 374 U.S. 424, 429 (1963). Pervasive national regulation may show only that a problem is so complex that federal agencies must work along with state agencies to solve it. DeCanas v. Bica, 424 U.S. 351, 357-60 (1976); New York Dep't of Social Servs. v. Dublino, 413 U.S. 405, 413, 415 (1973).

The argument based on the inherent preemptive effect of pervasive national regulation 
"potential conflict" in finding preemption necessary to ensure performance of these duties. ${ }^{30}$ National law may leave conduct free of regulation by not imposing duties ${ }^{31}$ or by granting privileges or rights to engage in such conduct. ${ }^{32}$ These opportunities are most numerous when national law expressly grants "full freedom" for conduct. ${ }^{33}$ The

is derived from a dictum in Rice v. Santa Fe Elevator Corp., 331 U.S. 218, 230 (1947) ("federal regulation may be so pervasive as to make reasonable the inference that Congress left no room for the States"). Rice's holding, however, rested on an express preemption clause. $I d$. at 229 . In a companion case, Rice v. Board of Trade, 331 U.S. 247 (1947), there was no express preemption clause, see $i d$, at 253 , but there was comprehensive national regulation, $i d$. at $250-53$. Despite this comprehensive national regulation, most of the state law was upheld. Id. at 253,256 . The dictum in Rice v. Santa Fe Elevator Corp. was supported by citation to two cases. 331 U.S. at 230 . In one, Cloverleaf Butter Co. v. Patterson, 315 U.S. 148, 168-69 (1942), the preempted state regulation protected consumers most of whom resided in other states. $I d$. at 150, 166 (interstate consumers of reprocessed butter); see pp. 372-74 infra (relevance of class of people protected in preemption cases). But cf. Braden, Umpire to the Federal System, 10 U. CHI. L. REv. 27, 28-36 (1942) (criticizing Cloverleaf). In the other case, Pennsylvania R.R. v. Public Serv. Comm'n, 250 U.S. 566 (1919), the preempted state regulation protected people working in interstate commerce. See $i d$. at 567, 569 (crewmen on interstate railroad trains). But see Colorado Anti-Discrimination Comm'n v. Continental Air Lines, 372 U.S. 714, 725 (1963) (upholding state law protecting people working in interstate commercc; "impossible ... to believe" national regulation so pervasive as to preempt state law).

30. In some cases a national agency has a duty to specify the relationship between national law and conduct hindered by the laws of a state or locality, but has not yet performed this duty. "Potential conflict" exists because the agency might rule that sucl conduct is necessary to achieve a national statutory objective. In San Diego Bldg. Trades Council v. Garmon, 359 U.S. 236 (1959), for example, the NLRB had not yet determined whether to prohibit or protect union activity that a state court had punished. Similarly, the warehouse financing hindered by the state regulation upheld in Rice v. Santa Fe Elevator Corp., 331 U.S. 218, 237 (1947), had not yet been required by the Secretary of Agriculture.

"Potential conflict" should be distinguished from "future hindrance," which exists when the relationship between state law and private conduct is speculative. A state agency may have authority to hinder certain conduct, but may not yet have exercised this authority. By itself, the mere possibility of future hindrance may be insufficient to create a concrete dispute. See, e.g., Askew v. American Waterways Operators, Inc., 411 U.S. 325, 336-37 (1973).

When past hindrances have created a concrete dispute, courts may consider the probability of future hindrance. See, e.g., City of Burbank v. Lockheed Air Terminal, Inc., 411 U.S. 624, 628, 638-39 (1973); Cloverleaf Butter Co. v. Patterson, 315 U.S. 148, 168.69 (1942). A high probability of future hindrance may be inferred from earlier cases showing a persistent hostility to the hindered activity. See p. 388 infra (persistent hostility as one of four factors leading to wholesale preemption).

31. For example, in Hines v. Davidowitz, 312 U.S. 52 (1941), the Court held that because national law failed to impose on aliens a duty to register in police stations or to carry identification cards, states were barred from imposing these duties. $I d$. at 73.74. But national failure to impose a duty often has no preemptive effect. In Southern Pac. Co. v. Arizona ex rel. Sullivan, 325 U.S. 761 (1945), congressional refusal to require railroads to use short trains was cited as a reason for upholding a state law imposing this requirement. Id. at 764-66.

32. See, e.g., 47 U.S.C. $\$ 326$ (1970) (protecting free speech rights of radio broadcasters); 46 U.S.C. $\$ 251$ (1970) (privileges of vessels in coasting trade).

33. See, e.g., Hill v. Florida ex rel. Watson, 325 U.S. 538 (1945) (preempting, on basis of 29 U.S.C. $\S 151$ (1970), a state law barring convicted felons from serving as union business agents); 29 U.S.C. $\$ 151$ (1970) (protecting union members' full freedom to designate representatives). 
Court has sometimes referred to "permitted" or "protected" conduct in discussing the opportunities. ${ }^{34}$

Conduct can be hindered by state legislation in direct and indirect ways. States hinder conduct directly by forbidding it or by imposing penalties on it. ${ }^{35}$ In Youngdahl $v$. Rainfair, Inc. ${ }^{36}$ for example, a state court enjoined union members from verbally harassing strikebreakers. The union argued that this prohibition restricted workers in the exercise of their national statutory right to engage in "concerted activity" ${ }^{37}$ for the purpose of collective bargaining or other mutual aid.

States may also hinder conduct directly by conditioning the opportunity to engage in the conduct on compliance with certain requirements. The burden of meeting these requirements may reduce an actor's ability or willingness to engage in the conduct in question. In Askew v. American Waterways Operators, Inc. ${ }^{38}$ for example, state law imposed very high oil spill financial responsibility requirements on vessels navigating the state coast. Vessel operators and trade associations noted the impossibility of compliance with state law, and showed that the state law restricted opportunities existing under national inspection and licensing laws. ${ }^{39}$

States may hinder conduct indirectly by reducing the willingness or ability of third parties to cooperate with it. In Florida Lime \& Avocado Growers, Inc. v. Paul, ${ }^{40}$ California forbade distributors to sell fruit that failed to pass an "oil content" test. Florida distributors argued that this test had been expressly rejected by the Department of Agriculture and that the test reduced their ability to market fruit in cooperation with the Department's performance of its statutory duty to foster "orderly marketing" of fruit. ${ }^{41}$

States may also hinder conduct indirectly by increasing the willingness or ability of third parties to hinder the conduct. In $U A W v$. Russell, ${ }^{42}$ the state allowed juries to require that union members pay punitive damages to strikebreakers. The union argued that such law-

34. E.g., Lodge 76, Int'l Ass'n of Machinists v. Wisconsin Employment Relations Comm'n, 427 U.S. 132, 140-46 (1976); Hines v. Davidowitz, 312 U.S. 52, 74 (1941).

35. Prohibition of dutiful conduct, see pp. 366-69 supra, is a particular kind of direct hindrance of national duties. It is analyzed separately from other kinds of hindrance because it raises simpler questions. See id.

36. 355 U.S. 131 (1957).

37. Brief for Petitioners at 75-76, 86-90.

38. 411 U.S. 325 (1973).

39. Brief of Appellees American Waterways Operators, Inc. at 40-41; Brief of Appellees American Institute of Merchant Shipping at 24, 40-42.

40. 373 U.S. 132 (1963).

41. Appellants' Brief at 31-33, 39-40, 44-51, 59, 88-89; see 7 U.S.C. $\$ 602$ (1976) (Secretary's duty).

42. 356 U.S. 634 (1958). 
suits restricted the union workers' "full freedom of association ... for ... mutual aid or protection." $\$ 3$ The union also argued that such lawsuits hindered the NLRB's performance of its statutory duty of "interbalancing" the interests of participants in labor disputes.4t

Thus states may hinder, directly or indirectly, the exercise of opportunities or the performance of duties existing under national law. Yet in Youngdahl v. Rainfair, Askew v. American Waterways Operators, Inc., Florida Lime \& Avocado Growers, Inc. v. Paul, and UAW v. Russell, hindrance failed to preempt state law. Hindrance has been preemptive only under certain circumstances. To identify these circumstances, it is necessary to examine various aspects of the preemption question more closely.

\section{Hindrance of the Achievement of National Objectives-An Analysis of the Relevant Factors}

In order to elucidate the problems presented in hindrance cases, this section will first examine one key factor-the protection provided by the state law in question. It will then seek to analyze the decision that a court must make as it attempts both to state the objective being pursued by a national statute, and to infer whether a particular form of conduct is necessary to the achievement of that objective and is being hindered by state law. Finally, it will explore the decision a court must make about how broad its preemption ruling will be.

\section{A. The Protection Provided by State Law}

An attempt to make sense of past hindrance cases must begin with an examination of the various interests that a state may seek to protect. This factor has often been determinative of the outcome in cases involving state laws that interfere with duties or opportunities created by the federal government. A state engages in extraterritorial protection when it protects people mostly outside its borders, and in territorial protection when it protects people mostly inside its borders. This distinction "is a fundamental one." 45 When a state law aims at extraterritorial protection and hinders the performance of national duties, courts have generally held that the law is preempted. State laws aimed at territorial protection are much less likely to be preempted.

43. National Labor Relations Act $\S 1,29$ U.S.C. $\$ 151$ (1970); see Brief for Petitioners at $20-23,58-64$.

44. Brief for Petitioners at 20, 22-29, 35-38, 56-57, 62 .

45. Florida Lime \& Arocado Growers, Inc. v. Paul, 373 U.S. 132, 145 (1963). 
For many years, national law imposed on the Department of Agriculture a duty to foster healthful production of butter; ${ }^{46}$ it still imposes on the Department a duty to foster interstate trading of tobacco ${ }^{47}$ and fruit. ${ }^{48}$ In Cloverleaf Butter Co. v. Patterson, ${ }^{49}$ a state law prevented a dairy from submitting butter to the Department for inspection. In Campbell v. Hussey,50 state labeling requirements enabled buyers to discriminate among tobaccos from different states, thus increasing the buyers' ability to avoid interstate trade with certain states. In Florida Lime \& Avocado Growers, Inc. v. Paul, ${ }^{51}$ decided two years after Campbell, state law forebade distributors to sell part of the Florida avocado crop, thus hindering interstate trade in fruit. The state laws in Cloverleaf and Campbell, which protected buyers mostly outside state borders, ${ }^{52}$ were preempted. But in Florida Lime the Court upheld the state's attempt to protect "the interests of that State's consumers of the fruit."'s3

The distinction between territorial and extraterritorial protection was also relevant when states hindered the FBI in the performance of its duties in Pennsylvania v. Nelson ${ }^{54}$ and Uphaus v. Wyman. ${ }^{55} \mathrm{Na}-$ tional law imposed on the FBI a duty to prevent sedition against national or state governments. ${ }^{56}$ State investigations of sedition reduced the willingness and ability of third parties to give information to the FBI. ${ }^{57}$ On the basis of this indirect hindrance, a state prosecution for sedition against the national government was preempted in Nelson. ${ }^{58}$ But in Uphaus the Court held that the rationale of Nelson did not preempt a state investigation of sedition against the state itself. ${ }^{59}$ Thus

46. Int. Rev. Code of $1939 \S 2325$ (repealed 1976).

47. See 7 U.S.C. $\$ 511 a$ (1976).

48. 7 U.S.C. $\$ \$ 601-602$ (1976).

49. 315 U.S. 148 (1942).

50. 368 U.S. 297 (1961).

51. 373 U.S. 132 (1963).

52. Ninety percent of the butter subject to state inspection in Cloverleaf was shipped to buyers outside the state. 315 U.S. at 150,166 . Nearly $100 \%$ of the tobacco subject to state regulation in Campbell was sold to out-of-state buyers. 368 U.S. at 298-99.

53. 373 U.S. at 145. The Court in Florida Lime distinguished Cloverleaf in terms of the different character of the protected class. It distinguished Campbell on other grounds, by emphasizing that a congressional desire for uniformity was a key factor in the latter case. Id. at 146-47. But see p. 384 infra (dissenters in Florida Lime found congressional desire for uniformity).

54. 350 U.S. 497 (1956).

55. 360 U.S. 72 (1959).

56. 18 U.S.C. $\$ 2385$ (1976).

57. See, e.g., Pennsylvania v. Nelson, 350 U.S. 497, 506-07 (1956) (quoting warnings of President and FBI Director against state agencies' interference with information flow to FBI).

58. See 350 U.S. at 499, 505.09 (sedition against United States is not local offense; state hindrance of FBI is preempted).

59. 360 U.S. at 76. 
hindrance of dutiful conduct preempted a state's attempt at extraterritorial protection, but not at territorial protection. ${ }^{60}$

Territorial protection of vital interests, on the other hand, is the category that is most impervious to preemption. If state laws protect people mostly inside the state from physical injury, they have generally been upheld even if they substantially hinder conduct that appears necessary to achieve a central purpose of national law. For example, in Maurer $v$. Hamilton ${ }^{61}$ a national statute declared it an express "policy of Congress to regulate transportation by motor carriers in such manner as to ... foster sound economic conditions" and to "promote adequate, economical, and efficient service by motor carriers." ${ }^{2}$ The statute commanded that "[i]t shall be the duty of the [ICC] [t]o regulate common carriers by motor vehicle as provided in this part." ${ }^{3}$ It also protected "the right of the carrier to add to his or its equipment and facilities ... as the development of the business and the demands of the public shall require." ${ }^{44}$ To exercise this right, a carrier attempted to use "car over cab" trailers to improve the economy and efficiency of its interstate operations. But state law forbade these trailers as unsafe ${ }^{65}$ and thus forbade conduct that appeared instrumental to the express purpose of national law. Moreover, the ICC had studied these trailers and concluded that they should not be prohibited as unsafe. ${ }^{68}$ The state prohibition thus appeared to hinder the ICC's performance of its express duty of fostering economical transportation. Yet the Court unanimously upheld the state law. ${ }^{07}$ Noting the state finding that the trailers were unsafe, the Court repeatedly stressed the need to protect human life from highway ac-

60. One preemption case indicates that certain regulations of aliens can only bc justified as extraterritorial protection. In Hines v. Davidowitz, 312 U.S. 52 (1941), Pennsylvania argued that its alien registration statute combatted a threat to life and property inside the state. See Brief for Appellants at 7-9, 13, 15, 22. But the Court countered that the aliens in question were "perfectly law-abiding." 312 U.S. at 66. Discrimination against and among such foreign nationals was an aspect of the foreign relations power, which the national government exercises to protect the states as a whole. Id. at 63-66. A recent case, Douglas v. Seacoast Prods., Inc., 431 U.S. 265 (1977), resembles Hines because it indicates that aliens cannot be deemed to pose any distinctive hazard to state interests. See id. at 285 \& n.21. But cf. DeCanas v. Bica, 424 U.S. 351, 355-57 (1976) (state law against employment of illegal aliens is justifiable as protection of workers within state).

61. 309 U.S. 598 (1940).

62. Motor Carrier Act of 1935, ch. $498, \S 202$ (a), 49 Stat. 543 (1935) (current version at 49 U.S.C. preceding $\$ I(1970))$.

63. Id. $\$ 204$ (a) (current version at 49 U.S.C. $\$ 304$ (a) (1970)).

64. Id. $\$ 208$ (a) (current version at 49 U.S.C. $\$ 308(a)(1970)$ ).

65. 309 U.S. at 599-601.

66. Id. at 602 .

67. Id. at 599, 617; see note 84 infra (rationale of Maurer). 
cidents. ${ }^{68}$ In light of this need; and absent a more explicit congressional directive, the relation between the national law and the carrier's conduct did not immunize this conduct from state prohibition. ${ }^{69}$ Cases before and after Maurer have similarly preserved state protection of human life. ${ }^{70}$

Yet Maurer marked a significant change in the method by which the Court preserved state power to protect vital interests. Prior to the 1930 s the Court often avoided preemption by simply invalidating national laws that might arguably have restricted state power to protect people inside state borders. During that era the Court followed the doctrine that national and state regulation were mutually exclusive: ${ }^{71}$

68. Id. at $600.01,605-06,608-11,616$.

69. See id. at 614-17.

70. See, e.g., Head v. New Mexico Bd. of Examiners, 374 U.S. 424, 428-29 (1963) (state restriction addressed to health); California v. Zook, 336 U.S. 725 (1949) (safety); Atlantic Coast Line R.R. v. Georgia, 234 U.S. 280 (1914) (safety); Stcamship Co. v. Joliffe, 69 U.S. (2 Wall.) 450, 460, 463 (1865) (safety). But see pp. 365, 368 supra \& pp. 379-81 infra (state protection of safety preempted in certain cases).

These cases and others, see, e.g., Florida Lime \& Avocado Growers, Inc. v. Paul, 373 U.S. 132 (1963) (state anti-fraud law); Savage v. Jones, 225 U.S. 501 (1912) (same), contradict the thesis of Note, supra note 2, at 626-27, 639 (indicating Court before 1930 made "expansive judicial assessments of federally regulated subject matter" and in Warren era showed "little regard for countervailing state concerns").

One commentator, see Note, Pre-emption as a Preferential Ground: A New Canon of Construction, 12 Sr.s. L. REv. 208, 220 (1959), has suggested that Maurer is inconsistent with Castle v. Hays Freight Lines, Inc., 348 U.S. 61 (1954). But the state laws in Maurer and Castle prohibited conduct bearing different relationships to national law. In Maurer state law forbade all trucking companies to use a particular trick. In Castle a state agency forbade a particular truching company to use certain public highways specified as routes by that company's ICC certificate of convenience and necessity. As the Court in Castle stressed, national law created special procedural requirements for notice, hearing, and a finding of willful violation as safeguards against abridgement of this route certificate. Id. at 63-64. See generally Reich, The New Property, 73 Y'ALC L.J. 733 (1964) (procedural safeguards protect entitlements to gorernment benefits).

By bypassing these national procedural safeguards, the state had imposed a "suspension or revocation of an interstate carrier"s.. . right to operate" on the public highways specified in its certificate. 348 U.S. at 64 . No comparable procedural safeguards protected the carrier's right to use an unsafe truck in Maurer. Moreover, by preempting wholesale exclusion of a particular firm from operation in the state, Caslle only prevented use of one particular penalty for violation of the state weight-limit laws. The states' ability to enact and enforce evenhanded safety standards for trucking equipment and operation was only slightly restricted. Accord, City of Chicago v. Atchison, T. \& S.F. R.R., 357 U.S. 77, 88.89 (1957) (city may not impose licensing scheme on interstation transfer vehicles, but may impose "general safety regulations" for operation of vehicles).

71. See D. Engdahl, Constitutional Power: Federal and State 325-27 (1974). This broad rule of mutual exclusivity may have been a response to circumstances including the persistent hostility of states to the national government and the relationships fostered by national law, see, e.g., J. Calhoun, The Fort Hill Address 2-3 (Va. Comm'n on Const. Gov't 1960); Warren, Federal and Stale Court Interference, 43 HARv. L. Rev. 345, 354-57 (1930) (state opposition to fugitive slave act and federal military), and the inability of overburdened federal courts to respond to this hostility on a case-by-case basis, see HarT \& WECHSLER, supra note 24, at 36-40, 59-60. Similar circumstances have led courts to announce a relatively broad rule of precmption in ccrtain modern cases. See p. 388 infra. 
once Congress regulated a subject, the states could not regulate it. ${ }^{72}$ The converse therefore became doctrine as well: the only way to allow states to protect vital interests was to deny Congress's power to protect them. ${ }^{73}$ This doctrine of mutual exclusivity was sometimes stated only as dictum ${ }^{74}$ and was sometimes used to justify holdings also justifiable on narrower grounds. ${ }^{75}$ In preemption cases, the Court often allowed states to protect life by regulating the participants in activity regulated by Congress. 76

After 1930 the doctrine of mutual exclusivity was discarded in preemption cases. ${ }^{i 7}$ At about the same time, the authority of Congress generally was broadened. ${ }^{8}$ This expansion of congressional authority was possible partly because the Court undertook to avoid preemption of state protection of vital interests, while at the same time validating national law. This approach required a painstaking examination of the facts of each preemption case, an examination apparently not required by the simple formula of mutual exclusivity. If the Court found that vital interests were protected by the state law, it held that national law

72. See, e.g., Charleston \& W.C. Ry. v. Varnville Furniture Co., 237 U.S. 597, 603-04 (1915) (alternative ground).

73. See, e.g., Carter v. Carter Coal Co., 298 U.S. 238, 299 (1936); Hammer v. Dagenhart, 247 U.S. 251, 273-76 (1918), overruled, United States v. Darby, 312 U.S. 100 (1941). Consistently applying its mutual exclusivity test to both state and federal law, the Count sometimes used cases addressed to state law as authority in cases addressed to national law. See Kidd v. Pearson, 128 U.S. 1, 21 (1888) (dictum in case upholding state law; relied on to strike down national laws in Carter and Hammer).

74. E.g., Houston v. Moore, 18 U.S. (5 Wheat.) 1, 21-25 (1820) (stating broad rule excluding state regulation of federal armed forces but upholding state court-martial of militia officers for disobeying federal command); see Arnold, The Power of State Courts to Enjoin Federal Officers, 73 YALE L.J. 1385, 1399-1401 (1964) (viewing Houston as striking case in favor of state regulation).

75. For example, the Court declared a broad exclusivity rule in Prigg v. Pennsylvania, 41 U.S. (16 Pet.) 539, 608, 610, 617-18, 626 (1842). A national law imposed upon magistrates a duty to aid the return of fugitive slaves into captivity. By forbidding kidnapping, an abolitionist state law prohibited the performance of this national duty. Prohibition of dutiful conduct, see pp. 367-69 supra, thus provided a narrower ground for decision in Prigg.

76. The Court accomplished this result by defining narrowly the "field" that a national statute regulated. For example, Atlantic Coast Line R.R. v. Georgia, 234 U.S. 280 (1914), involved a national law requiring a large number of locomotive safety devices, but not requiring electric headlights. State regulation of the separate field of electric locomotive headlights was upheld. Id. at 293-94. Even when Congress had specifically forbidden national agencies to impose a requirement, the Court upheld state imposition of this same requirement to protect people from deception or physical injury. See, e.g., Savage v. Jones, 225 U.S. 501, 532-33 (1912).

77. D. EnGDAHL, supra note 71 , at $327-30$. This change in formal doctrine may have reflected the federal courts' improved administration, see HART \& WECHSLER, supra note 24, at 39-4I, 60-61, and consequent greater ability to make case-by-case determinations.

78. See, e.g., Wickard v. Filburn, 317 U.S. 111 (1942) (upholding federal restriction on farmer's raising of wheat for consumption on his own farm); NLRB v. Jones \& Laughlin Steel Corp., 301 U.S. 1 (1937) (upholding National Labor Relations Act). 
was not preemptive, and thus not invalid. ${ }^{79}$ If it found otherwise, preemption was much more likely. This approach required scrutiny of the duties and opportunities created by the national law to determine whether immunizing them from state law was a necessary consequence of enforcing national law.

Before 1930, for example, the Court in some cases had prevented states from imposing requirements that a national agency had decided not to impose. ${ }^{80}$ As congressional authority began to expand, the Court in 1935 revised the nondelegation doctrine to limit the delegated authority of national agencies to decide whether requirements should be imposed. ${ }^{81}$ This doctrine proved unworkable, however, and was not used to restrict agency authority after $1936 .{ }^{82}$ At about the same time, Maurer v. Hamilton ${ }^{83}$ unanimously upheld state imposition of a requirement that a national agency had refused to impose. ${ }^{84}$ In 1949 ,

79. This policy is consistent with the Court's practice of avoiding unnecessary resolution of constitutional questions. See Ashwander v. TVA, 297 U.S. 288, 346-48 (1936) (Brandeis, J., concurring). For a discussion of constitutional questions about the scope of congressional power, see D. ENGDAHL, supra note 71, at 11-41, 68-70, 80-84, 95-104. A state can still argue that national statutes are unconstitutional to the extent that they prevent a state from protecting people inside its borders. See, e.g., Brief of Appellants at 12-15, 41-54, 63-66, Askew v. American Waterways Operators, Inc., 411 U.S. 325 (1973). But this question need not be reached if restriction of state powers is not a necessary effect of the national statute. See, e.g., Askew v. American Waterways Operators, Inc., 411 U.S. 325 (1973) (unanimously denying that national statutes involved in case preempt state law). But see pp. 368-69 supra (in some cases effect of national statute on state protection of people cannot be denied).

80. As Congress began to delegate broad authority to national agencies, the Court denied that the mere grant of authority itself preempted state law. Missouri, Pac. Ry. v. Larabee Flour Mills Co., 21I U.S. 612, 623 (1909). But after the agency had exercised its authority by imposing certain requirements, states might be barred from imposing additional requirements. Napier v. Atlantic Coast Line R.R., 272 U.S. 605, 612-13 (1926).

Yet Missouri, Pacific may be distinguished from Napier by another factor. In Napier the state laws attempted to protect participants in interstate commerce. 272 U.S. at 606-07. Thus the case differed from others such as Missouri, Pacific, in which a state attempted to protect people inside the state from the conduct of participants in interstate commerce. See, e.g., Missouri, K. \& T. Ry. v. Haber, 169 U.S. 613, 635-37 (1898) (fact that national bureau protects against disease does not prevent state from protecting people within state); cf. p. 372 supra (distinguishing territorial from extraterritorial protection).

81. A.L.A. Schechter Poultry Corp. v. United States, 295 U.S. 495 (1935). See generally $1 \mathrm{~K}$. DAvis, ADMinistrative LAW Treatise $\$ \S$ 2.01-2.16 (1958).

82. I K. DAvis, supra note 81 , at $\$ \S 2.01-2.06$.

83. 309 U.S. 598 (1940).

84. Id. at 602; see pp. $374-75$ supra. Maurer did not, however, overtly discard the doctrine of mutual exclusivity. Instead, it distinguished the field of state safety regulation of truck size and weight from the field of ICC safety regulation of truck equipment. It then placed "car over cab" transportation in the field subject to state regulation. 309 U.S. at 609-17. Thus, although the doctrine of mutual exclusivity did not control the holdings of preemption cases after 1933, see D. ENGDAHL, supra note 71, at 327-30, this doctrine influenced the reasoning of preemption decisions until California v. Zook, 336 U.S. 725, 729-33 (1949). 
California $v$. Zook ${ }^{85}$ upheld state regulation of the very action regulated by a national agency, although the state penalties for this action were more severe than the penalties set by the agency. ${ }^{80}$ The Court explained its decision by emphasizing that the state law protected people mostly inside its borders from fraud and physical injury. ${ }^{87}$ The Court made it apparent that preemption of such laws was not a necessary consequence of national regulation of this same area. ${ }^{88}$

Since 1930 the Court has often refused to preempt state attempts at territorial protection of vital interests. ${ }^{89}$ Protection of people mostly inside state borders from physical injury has been upheld, even if the state law in question affects interstate or international activities. ${ }^{30}$ In-

85. 336 U.S. 725 (1949).

86. Id. at 736 (state may impose more severe penalties); see id. at $746-47 \&$ n.11, 758 (Burton, J., dissenting) (emphasizing that state penalties are more severe than federal penalties).

87. Id. at $734-35,737-38$.

88. Id. at $729-33$.

89. See note 70 supra (citing cases). The kind of interest protected by a state law thus may be an important factor in preemption cases. If a state law "is a measure directly addressed to protection of the public health," it "thus falls within the most traditional concept of what is compendiously known as the police power." Head v. New Mexico Bd. of Examiners, 374 U.S. 424, 428 (1963) (footnote omitted). Preemption of state laws that have the effect of protecting such public interests may be found unnecessary to achieve national statutory objectives. See, e.g., id. at 432; id. at 445.46 (Brennan, J., concurring); Southern Pac. Co. v. Arizona ex rel Sullivan, 325 U.S. 761, 764-66 (1945) (state protection of safety); H.P. Welch Co. v. New Hampshire, 306 U.S. 79, 85 (1939) (state protection of safety). But cf. pp. 386-87 infra (distinguishing state protection of safety from state assistance to one of participants in economic contest).

Environmental protection laws may protect vital interests if they regulate a health hazard or source of personal injury. See, e.g., Huron Portland Cement Co. v. City of Detroit, 362 U.S. 440, 442, 445 (1960). However the status of a law may change. For example, laws aimed at marine oil pollution were once thought to protect health. See Askew v. American Waterways Operators, Inc., 411 U.S. 325, 333 n.5 (1973). But later studies belittled the health hazards of marine oil pollution, see G. AHERN, OIL AND THE Outer Coastal Shelf: The Georges Bank Case 75-76 (1973) (criticizing earlier study linking oil pollution and cancer); Hunt, The Petroleum Problem, 18 Oceanus 4, 5 (1974) (quantities of carcinogens in oil-contaminated fish do not exceed quantities in many human foods), and even questioned whether oil had any serious impact on the marine environment, Abelson, Oil Spills, 195 ScI. 137 (1977). Subsequently, the Court preempted some state oil tanker regulation, without addressing the possibility of any health hazards. See Ray v. Atlantic Richfield Co., 435 U.S. 151 (1978).

90. See, e.g., Askew v. American Waterways Operators, Inc., 411 U.S. 325 (1973) (statc regulation of maritime liability rules for supertankers in interstate and international trade). This deference to state law applies even when the law protects values less compelling than human life. See Florida Lime \& Avocado Growers, Inc. v. Paul, 373 U.S. 132, 143 (1963) (California anti-fraud law required modification of fruit-picking schedules in Florida); Colorado Anti-Discrimination Comm'n v. Continental Air Lines, 372 U.S. 714 (1963) (state anti-discrimination regulation of crew employment relations on interstate airliners); Penn Dairies, Inc. v. Milk Control Comm'n, 318 U.S. 261, 275 (1943) (state regulation of milk supply raising sost of United States government operations during wartime national emergency).

Advocates of preemption frequently argue that there is a "dominant federal interest" in interstate or international activities, and that this interest requires the preemption of state laws affecting these activitics. See, e.g., Brief of Respondents at 2.9, DeCanas v. Bica, 
novative laws have thus been upheld because they protect people inside state borders against serious dangers, even if the dangers spring from a new technological or social development. ${ }^{91}$ Such innovative laws have come within the scope of what the Court calls "the tradition of 'usual police powers." "'s2

Although it almost appears that there is a general rule against the preemption of state laws protecting the vital interests of state citizens, two cases suggest that this rule is not absolute, and that special circumstances can sometimes lead to preemption of even these laws. In Minnesota v. Northern States Power Co., ${ }^{33}$ the Supreme Court issued a memorandum affirmance of a lower court decision immunizing nuclear power plants from state control of radioactive emissions. The national statute involved was expressly designed, inter alia, "to en-

424 U.S. 951 (1976); Brief of the United States as Amicus Curiae at 23-35, Head v. New Mexico Bd. of Examiners, 374 U.S. 424 (1963). But see, e.g., DeCanas v. Bica, 424 U.S. 35I, 355.56 (1976) (regulation of employment of illegal aliens protects workers inside state and is therefore within state's "broad authority"); Head v. New Mexico Bd. of Examiners, 374 U.S. 424, 428-32 (1963) (state law protects health and is matter of "fundamentally local concern"). This argument ignores the crucial question in preemption cases. According to the supremacy clause, U.S. CoNST. art. VI, $\$ 2$, the duty to give effect to a valid national law is always dominant over "contrary" state laws. The crucial question is whether state law is contrary to national law, so that preemption of state law is necessary to give effect to the national law. See pp. 382-83 infra. But see Hirsch, stupra note 2, at 530, 532 (presence of "dominant" federal interest is objective "factor" in decision on preemption question).

The argument that preemption turns on the presence or absence of a "dominant" federal interest is based on a dictum in Rice v. Santa Fe Elevator Corp., 331 U.S. 218, 230 (1947) "Act of Congress may touch a field in which the federal interest is so dominant" that preemption is necessary). Cf. note 29 supra (Rice dictum about "pervasive national regulation"). The holding of Rice rested on application of an express preemption clause, 331 U.S. at 229 . This dictum was supported only by a citation to Hines v. Davidowitz, 312 U.S. 52 (1911); but in Hines the state law regulated "perfectly law abiding" aliens, rather than protecting against some threat to the state's residents. Id. at 66 .

Recently, Hines served as authority for the decision in a case in which state courts discriminated among aliens to induce foreign governments to recognize the ownership rights of United States citizens in general. Zschernig v. Miller, 389 U.S. 429 (1968); see pp. $372.74 \&$ note 60 supra (discussion of extraterritorial protection). In contrast, a state law with international repercussions may be upheld if it protects people mostly inside state borders. See DeCanas v. Bica, 424 U.S. 351, 355-57 (1976) (state regulation of employment of illegal immigrants); Askew v. American Waterways Operators, Inc., 411 U.S. 325, 327, $338-39$ (1973) (state regulation of shipping). But cf. Ray v. Atlantic Richfield Co., 435 U.S. 15I, 166.67 (1978) (congressional support for international specification of oil tanker design standards militates against state regulation).

91. For example, interstate car pools posed a novel threat to safety, to which California had responded for only a few years before California v. Zook, 336 U.S. 725 (1949), was decided. Despite its short history, this response was upheld. Id. at 734-37; see, e.g., DeCanas v. Bica, 424 U.S. 351, 352 \& n.l (1976) (state law enacted in 1971 to respond to problem of employment of illegal aliens); Askew v. American Waterways Operators, Inc., 411 U.S. $325,335,341-43$ (1973) (state regulation of oil spill liability rules in response to development and increasing use of supertankers).

92. California v. Zook, 336 U.S. 725, 734 (1949); see DeCanas v. Bica, 424 U.S. 351, 354-57 (1976); Askew v. American Waterways Operators, Inc., 411 U.S. 325, 328-29, 333-43 (1973).

93. 405 U.S. 1035 (1972) (affirming 447 F.2d 1143 (8th Cir. 1971)). 
courage maximum scientific and industrial progress"9t and "to encourage widespread participation in the development and utilization of atomic energy for peaceful purposes to the maximum extent consistent with the common defense and security and with the health and safety of the public." ${ }^{25}$ To prevent hindrance of the activities of the Atomic Energy Commission directed at these objectives, the Court preempted state regulation despite the possibility that lax regulation by the Commission would endanger human life. ${ }^{96}$ In Ray v. Atlantic Richfield Co., ${ }^{\text {"7 }}$ the Court immunized oil tankers from state regulation of vessel equipment and size. According to the Court, the national statute had the objective of securing an international, uniform system of regulation for these vessel safety features. ${ }^{98}$ To prevent hindrance of Coast Guard conduct directed at this objective, the Court preempted state regulation ${ }^{39}$ despite the possibility that lax Coast Guard regulation would result in oil pollution, thus perhaps ${ }^{100}$ endangering human life.

These two cases may be read to indicate that there exists only a heavy presumption against preemption of state laws protecting vital interests. This presumption was overcome by the presence of several factors in addition to the problem of state restriction of a federal agency's ability to achieve a national statutory objective. ${ }^{101}$ First, the development of the industry hindered by state law was important to national security. Because it was initially developed by the federal government, and because it is so closely linked to national security, the use of atomic energy is arguably much more a matter of federal concern than are other activities of public utilities. ${ }^{102}$ Similarly, the tankers that Washington state sought to regulate are crucial links between the Trans-Alaska pipeline and the "lower 48" states, and thus

94. Atomic Energy Act of 1954, $\$ 3(a)$, 42 U.S.C. $\S 2013$ (a) (1970).

95. Id. $\$ 3(\mathrm{~d}), 42$ U.S.C. $\$ 2013(\mathrm{~d})(1970)$.

96. 405 U.S. 1035 (1972) (affirming 447 F.2d 1143 (8th Cir. 1971)).

97. 435 U.S. $151(1978)$.

98. Id. at 163, 166-68 (discussing 46 U.S.C. $\$ \$ 391$ (7)(B)-(D) (Supp. V 1975)).

99. See 435 U.S. at 168-69, 178 (invalidating state design requirements and tanker size limit; upholding state tugboat escort requirements).

100. Some researchers recently have belittled the possibility that oil spills endanger human health. See G. AHERN, supra note 89, at 75-76; Hunt, supra note 89, at 5 . In its brief defending the tanker law, Washington state never asserted that oil spills endangered human health, but instead focused on the effect of spills on fisheries and recreational opportunities. See Brief of Appellants at 11-17, Ray v. Atlantic Richfield Co., 435 U.S. 151 (1978). In deciding the case the Court did not mention any possibility of health hazards.

101. See p. 379 supra.

102. See Northern States Power Co. r: Minnesota, 447 F.2d 1143, 1148 (8th Cir. 1971), aff'd mem., 405 U.S. 1035 (1972) (noting congressional findings on need for regulation to provide for "common defense and security"). 
are important to the national effort to limit dependence on foreign oil. ${ }^{103}$ Second, the federal statute at issue itself provided adequate protection for the vital interests at stake. The laws involved in Northern States and Ray both sought, among other things, to protect the public from accidents, ${ }^{104}$ and in both cases this purpose had been implemented by extensive regulations. ${ }^{105}$ Third, a national agency had decided to permit the conduct forbidden by the state. ${ }^{100}$ Finally, Ray may be read to require that the federal program allow for adequate attention to local needs and variations. ${ }^{107}$ Under these unusual circumstances, the states' authority to protect vital interests was overcome by the need to achieve urgent national objectives.

National objectives have also required preemption of state attempts to protect people from certain forms of economic duress. The national labor laws were designed in part to protect peaceful union conduct. ${ }^{108}$ Yet as recently as 1950 the Court upheld state protection of employers against peaceful union conduct on the grounds that this conduct amounted to economic duress. ${ }^{100}$ Eventually the Court preempted state attempts to protect employers from labor organizations. ${ }^{110}$ The Court has refused, however, to deprive individual strikebreakers, ${ }^{111}$ individual union members, ${ }^{112}$ and even individual supervisory em-

103. See Brief of Appellees at 4-5, Ray v. Atlantic Richfield Co., 435 U.S. 151 (1978); cf. H.R. REP. No. 414, 93d Cong., Ist Sess. 9-11 (1973) (authorization for trans-Alaska pipeline necessary to avoid "crippling fuel shortages" and to protect national security).

104. See p. 380 supra (statute in Northern Stales); Ray v: Atlantic Richficld Co., 435 U.S. 151, 165 (1978) (law "aims at insuring vessel safety and protecting the marine environment").

105. See Ray v. Atlantic Richfield Co., 435 U.S. 151, 162 nn.11-12, 170-71 (Coast Guard implementation); Northern States Power Co. s. Minnesota, 447 F.2d 1143, 1153 (8th Cir. 1971), aff'd mem., 405 U.S. 1035 (1972) (regulations of Atomic Energy Commission).

106. See Northern Stales Power Co. V. Minnesota, 447 F.2d 1143, 1145 (8th Cir. 1971), aff'd mem., 405 U.S. 1035 (1972) (Commission had approved construction of plant with radioactive discharge levels forbidden by state). In Ray, the Coast Guard had rejected the design requirements imposed by the state, Brief of Appellants at 16-17, Ray v. Atlantic Richfield Co., 435 U.S. 151 (1978), and had decided that restrictions on large tankers were necessary in only part of Puget Sound, whereas the state had sought to ban these tankers from the entire Sound. Ray v. Atlantic Richfield Co., 435 U.S. 151, 174-75, 178 (1978).

107. See 435 U.S, at 169.72 (state was still allowed to require pilots for entering and leaving port and to require tug escort; federal scheme also provided for detailed regulation of particular ports and waterways).

108. See 29 U.S.C. $\$ \$ 151,157,158$ (a) (1970).

109. See Building Scrr. Employecs Local 262 v. Gazzam, 339 U.S. 532 (1950) (injunction against peaceful picketing found to prevent duress and upheld against First Amendment attack); UAW Local 232 v. Wisconsin Employment Relations Bd., 336 U.S. 245 (1949) (state prohibition of peaceful partial strikes is not preempted).

110. See Lodge 76, Int'l Ass'n of Machinists $r$. Wisconsin Employment Relations Comm'n, 427 U.S. 132 (1976); Street, Elec. Ry. \& Motor Coach Employees Div. 998 v. Wisconsin Employment Relations Bd., 340 U.S. 383 (1951).

111. See UAW v. Russell, 356 U.S. 634 (1958).

112. See Farmer v. Carpenters Local 25, 430 U.S. 290 (1977) (union member's damage suit for infliction of emotional distress); Vaca v. Sipes, 386 U.S. 171 (1966) (damage suit 
ployees, ${ }^{113}$ of state protection against labor organizations. The Court has similarly refused to preempt state protection of "public safety and order."114 To explain such refusals, the Court has declared that state protection of this type cannot be preempted in the absence of "compelling Congressional direction." 115

\section{B. Inference of the Federal Objective}

If hindrance of the achievement of a national objective is to be found, it is necessary to know what that federal objective is. Some statutes expressly state their overall objectives in a "declaration of policy" or of "purpose," 116 or in sections that declare that certain policies are for "the public convenience and necessity." 117 But not all national statutes have such clauses. Without them, deciding the question of preemption requires an inference of the overall statutory objective.

The process of inferring an objective is both restrained and simplified by the fact that only a command with the force of national law has been deemed to override state law. The Constitution grants Congress a number of opportunities to regulate such activities as interstate commerce. ${ }^{118}$ It also grants Congress the authority "to make all Laws which shall be necessary and proper for carrying into Execution the foregoing Powers." 119 Since the Constitution commands that the laws of the United States shall be the supreme law of the land and that the

for breach of duty of fair representation). But see Street, Elec. Ry. \& Motor Coach Em. ployees v. Lockridge, 403 U.S. 274 (1971) (employee may not maintain state court suit against union for persuading employer to fire employee on grounds of nonpayment of union dues).

113. See Linn v. Plant Guard Workers Local 114, 383 U.S. 53 (1966).

114. Allen-Bradley Local 1111 v. Wisconsin Employment Relations Bd., 315 U.S. 740, 749 (1942).

115. San Diego Bldg. Trades Council v. Garmon, 359 U.S. 236, 244 (1959) (dictum) (citing cases in which refusing to preempt allowed states to protect citizens' rights to shelter and livelihood). This standard for the preemption of laws fundamental to state responsibility thus resembles the Court's standard for the restriction of opportunities fundamental to individual livelihood. See Shapiro v. Thompson, 394 U.S. 618, 658-61 (1969) (Harlan, J., dissenting) (citing cases in which exercise of rights enabled people to obtain food, shelter, and other necessities of life).

116. See, e.g., 7 U.S.C. $\$ \S 361 a-361 b$ (1976) (statute fostering agricultural research); 15 U.S.C. $\$ 1451$ (1976) (Fair Packaging and Labeling Act); 29 U.S.C. $\$ 151$ (1970) (National Labor Relations Act); 47 U.S.C. $\$ 301$ (1970) (statute regulating radio communications).

117. E.g., 49 U.S.C. $\$ 1303$ (1970) (statute fostering commercial aviation); see 33 U.S.C. $\S 1221$ (Supp. V 1975) (initial section states that statute is enacted "to prevent damage to" vessels and structures and "to protect" environment).

118. U.S. ConsT. art. I, $\$ 8$.

119. Id. cl. 18; see D. ENGDAHL, supra note 71, at 11-41, 68-70, 80-84, 95-104 (sources of congressional ability to restrict private conduct or state regulation that affects activities subject to congressional regulation). 
judiciary shall give effect to that law, ${ }^{120}$ judges have a duty to give effect to each national statute, construed in light of these constitutional grants of authority. The Constitution does not, however, impose a comparable duty to give effect to declarations in legislative history. ${ }^{121}$

Focusing on the statute itself and on the constitutional grant of power under which it was passed has been a workable method for determining the objectives of statutes that lack clauses declaring their purposes. In Wissner $v$. Wissner, ${ }^{122}$ for example, a federal statute had granted military personnel "the right to designate the beneficiary" of their national service life insurance policies, ${ }^{123}$ thereby increasing the benefits of enlistment in the military. Noting the constitutional power to raise armies, ${ }^{124}$ but without considering legislative history, the

120. U.S. CoNsT. art. VI, § 2; see Hirsch, supra note 2, at 515; Note, supra note 2, at 623.24 \& n.7.

121. Justice Jackson questioned the extent to which courts should consider legislative history when construing statutes:

The Constitution evidently intended Congress itself to reduce the conflicting and tentative views of its members to an agreed formula. It [is] expected to speak its will with considerable formality, after deliberation assured by three readings in each House. Its exact language requires Executive approval, or enough support to override a veto. How far, then, should this formal text and contract be qualified or amplified by expressions of one or several Congressmen in reports or debates which did not find place in the enactment itself?

Jackson, The Mfeaning of Statutes: What Congress Says or What the Court Says, 34 A.B.A.J. 535, 538 (1918). The Court has frequently refused to conform its holdings to declarations in legislative history. See note $\mathbf{5}$ supra. Compare Brief of Respondents at 16, 19-20, DeCanas v. Bica, 424 U.S. 351 (1976) (employment of illegal aliens was congressionally immunized from punishment) and Brief for Respondents at 11.13, Kewance Oil Co. v. Bicron Corp., 416 U.S. 470 (1974) (legislative commentary favoring disclosure of trade secrets) with DeCanas v. Bica, 424 U.S. 351, 357 (1976) (ouster of state authority must be clear and manifest) and Kewanee Oil Co. v. Bicron Corp., 416 U.S. 470, 483, 493 (1974) (Congress by silence has allowed states to prohibit disclosure of trade secrets). It has explained its decisions by declaring that

[a]n unexpressed purpose of Congress to set aside statutes of the states regulating their internal affairs is not lightly to be inferred .... Considerations which lead us not to favor repeal of statutes by implication . . . should be at least as persuasive when the question is one of the nullification of state power by Congressional legislation. Penn Dairies, Inc. v. Milk Control Comm'n, 318 U.S. 261, 275 (1943) (citations omitted). Legislative commentary need not be regarded as authoritative, partly because the objectives of a national statute can be inferred from the structure of duties (and coincident rights) expressly created by the statute itself. See, e.g., p. 384 infra. The express commands of a statute thus amount to an "instruction to administrators and courts to accomplish a definite result, usually the securing or maintaining of recognized social, political, or cconomic values." Radin, A Short Way with Statutes, 56 HARv. L. REv. 388, 407 (1942); see H. Hart \& A. SACks, The Legal Process 1144, 1156-57, 1285-86 (ed. 1958) (describing rules for implementing overall objective of statute); Frankfurter, Some Reflections on the Reading of Statutes, 47 Couvs. L. Rev. 527, 538-39 (1947) (distinguishing "purpose" of law from legislators' intention); Radin, supra, at 409, 418-23 (discussing concept of "purpose"); Radin, Statutory Interpretation, 43 HARv. L. REv. 863873 (1930) (opposing reliance on legislative history) [hereinafter cited as Statutory Interpretation].

122. 398 U.S. 655 (1950).

123. National Service Life Insurance Act of 1940, ch. 757, tit. VI, $\$ 601$ (g), 54 Stat. 1008 (current version at 38 U.S.C. $\$ 717$ (1970)).

124. U.S. Const. art. I, $\$ 8$, cl. 12 . 
Court discerned the overall objective of the statute: maintaining military morale. ${ }^{125}$ The Court then preempted a state community property rule that halved the benefits controlled by the national grant of rights to enlisted persons. ${ }^{126}$

Focusing on legislative history, in contrast, often introduces ambiguities into the process of deciding preemption cases. As Justice Jackson observed, "[i]t is a poor cause that cannot find some plausible support in legislative history." 127 In Florida Lime is Avocado Growers, Inc. $v$. Paul, ${ }^{128}$ the dissenting Justices found congressional support for "uniformity of regulatory programs" in the legislative history. ${ }^{129}$ But the majority focused on the statute itself. The statute's "declaration of policy" sought to achieve parity prices for the benefit of producers, a steady flow of produce to consumers, and such produce standards and inspection procedures "as will be in the public interest." ${ }^{130}$ By focusing on the legislature's authoritative statement, ${ }^{131}$ the Court resolved the ambiguity: uniformity should be valued only to the extent that it was necessary to further the interests expressed in this statement. Without considering legislative history ${ }^{132}$ the Court had already found no necessity for "exclusive federal regulation in order to achieve uniformity vital to national interests." 133 The interests expressed by Congress in the statute could be achieved without depriving consumers of state protection against deception. ${ }^{134}$ The Court therefore refused to deprive states of the power to protect these people, "in the absence of an unambiguous congressional mandate." 135

\section{Inference of Necessity and Hindrance}

Once the national objective is found, it is necessary to determine whether the state law in question substantially hinders conduct neces-

125. 338 U.S. at 660 .

126. Id. at 661 .

127. Jackson, supra note 121, at 538; see id. ("legislative history... often includes tentative rather than final views of legislators or leaves misrepresentation unanswered"). The ambiguity of legislative histories often arises from the fact that legislators hase many diverse reasons for their votes on a given bill, see Murdock v. City of Memphis, 87 U.S. (20 Wall.) 590, 618-19 (1875); Statutory Interpretation, supra note 121, at 870-71.

128. 373 U.S. 132 (1963).

129. Id. at 170,175 (White, J., dissenting).

130. 7 U.S.C. \$ 602 (1976).

131. 373 U.S. at 138,147 .

132. The Court instead derived its conclusion from an examination of the "subject matter," which it presented as an alternative to a search for an "explicit declaration of congressional design to displace state regulation." Id. at 143. "Subject matter" analysis attempts to determine whether making national regulation of an activity exclusive is necessary to achieve an express statutory objective. See pp. 387-88 \& note 157 infra.

133. 373 U.S. at 144; see notes $157 \& 160$ infra.

134. See 373 U.S. at $145-47$.

135. Id. at $146-47$. 
sary to the achievement of that objective. To determine whether conduct is necessary to achieve a statutory objective, the Court has focused on the conduct itself. As Florida Lime and Free v. Bland ${ }^{130}$ demonstrate, fraud or deception may be found unnecessary. The Court has repeatedly refused, as it did in Maurer $v$. Hamilton ${ }^{137}$ and California $v$. Zook, ${ }^{138}$ to deem the endangering of human life to be necessary to achievement of the statutory objective. ${ }^{130}$ In considering whether human needs should be deprived of the protection of state law, the Court has also asked whether national law establishes an adversarial system to protect all these needs. ${ }^{140}$

Thus states have been able to restrict opportunities for dangerous conduct left unrestricted by national law. ${ }^{141}$ In fact, a deliberate national refusal to impose the restrictions imposed by states has been used as a reason to uphold such state restrictions. ${ }^{142}$ Under certain conditions, however, relatively lenient regulation by a national agency may be found necessary to protect national interests, and may therefore preempt state attempts to provide increased protection for the vital interests of state residents. ${ }^{143}$

136. 369 U.S. 663, 670 (1962) (exception read into national bond regulations to avoid immunizing fraud from prohibition).

137. 309 U.S. 598 (1940); see pp. $374-75$ supra.

138. 336 U.S. 725 (1949); see p. 378 supra.

139. See pp. $374-78$ \& notes 70, 76, 89 supra (citing cases); cf. p. 368 supra (protection given to life as factor even in cases involving prohibition of dutiful conduct).

140. See p. 368 \& note 24 supra. This protective adversarial system may be an aspect of private economic competition, of the relationship between two government agencies, or of the procedural rules of a single agency. A private adversarial system of economic competition may be adequate to protect certain public interests. For example, the consumer interest in inexpensive goods may be protected by an employer's resistance to. union wage demands or by a manufacturer's copying of an unpatentable invention without the inventor's permission. See p. 386 infra ("economic balance" cases).

In contrast, "public safety and order" may require direct governmental protection. See pp. 381-82 supra (subjects of state protection). An adversarial government arrangement may be necessary to provide adequate opportunities for case-by-case representation and protection of all interests. No such adversarial system was present in Head v. New Mexico Bd. of Examiners, 374 U.S. 424 (1963), where a national statute "centralizing authority" in the FCC to restrict and to foster commercial radio, 47 U.S.C. $\$ \S 151,301$ 303 (1970), did not preempt state protection of listeners' health. See 374 U.S. at 428-32; id. at 437-38, 446-47 (Brennan, J., concurring). By contrast, the adversarial relationship between the Environmental Protection Agency and the Federal Aviation Administration provides an arrangement protecting both the safety and the quiet of localities. City of Burbank v. Lockheed Air Terminal, Inc., 411 U.S. 624, 629-32, 638-39 (1973). AIternatively, a single agency sis adversarial procedural system may protect diverse interests. In San Diego Bldg. Trades Council v. Garmon, 359 U.S. 236 (1959), the NLRB was available to provide both unions and management with representation in a quasi-judicial system.

141. See, e.g., Askew v. American Waterways Operators, Inc., 411 U.S. 325, 334-36 (1973); Youngdahl v. Rainfair, 355 U.S. 131 (1957); H.P. Welch Co. v. New Hampshire, 309 U.S. 79, 85 (1939); Reid v. Colorado, 187 U.S. 137, 148-50 (1902).

142. See, e.g., note 76 supra (citing cases); Head v. New Mexico Bd. of Examiners, 374 U.S. 424, 444 (Brennan, J., concurring) (national refusal to regulate nondeceptive ad. vertising). But cf. note 31 supra (contradictory cases).

143. See pp. $379-81$ supra. 
In a large number of cases, conduct has been deemed necessary not because of its individual contribution to a national objective, but because its interaction with the conduct of business competitors serves that objective. In these "economic balance" cases, which have involved federal patent law, ${ }^{144}$ labor law, ${ }^{145}$ securities law, ${ }^{146}$ and vessel licensing law, ${ }^{147}$ the conduct in question has four main characteristics. First, state regulation of this conduct was intended primarily as an aid to one party in a private economic contest. Second, the conduct itself was aimed at counteracting the actions of adversaries, thus creating an economic balance of power. Third, the process of economic competition served a national statutory objective. Fourth, the conduct immunized from state law was not fraudulent or dangerous to life. ${ }^{148}$

Determining the effect of a state law on the achievement of a national statutory objective requires analysis of each feature of the state law. The state law at issue in the 1941 case of Reitz $v$. Mealy, ${ }^{149}$ for example, deprived financially irresponsible tortfeasors of their driver's licenses. It also allowed them to prove financial responsibility by paying the tort claim. National bankruptcy law, however, discharged the debts of certain insolvent tortfeasors. The Court upheld the application of state law to these tortfeasors, stressing that it was not in derogation of national law because it was "not for the protection of the creditor merely" but instead for the protection of public safety. ${ }^{150}$

In 1962 the state law challenged in Kesler v. Department of Public

144. See, e.g., Compco Corp. v. Day-Brite Lighting Inc., 376 U.S. 234 (1964).

145. See, e.g., Lodge 76, Int'l Ass'n of Machinists v. Wisconsin Employment Relations Comm'n, 427 U.S. 132 (1976).

146. See Great Western United Corp. v. Kidwell, 577 F.2d 1256 (5th Cir. 1978).

147. See Douglas v. Seacoast Prods., Inc., 431 U.S. 265 (1977). The objective of the licensing statute in Douglas is unclear unless one reads the statute in light of the commerce clause, from which can be inferred the objective of national "economic interdependence," C. Black, Structure and Relationship in Constitutional Law 20, 21, 27-29 (1969); see pp. 382-84 supra (rationale and example of reading statutes in light of constitutional grants of authority).

148. Under such circumstances, preemption is necessary. For example, when the developers of certain unpatentable inventions used state unfair competition laws to prevent the manufacture of less expensive copies, thus gaining an advantage in their battle with competitors and interfering with pursuit of the national objective of promoting science and the useful arts, state law was invalidated. See Compco Corp. v. DayBrite Lighting Inc., 376 U.S. 234, 238.39 (1964); Goldstein, The Competitive Mandate: From Sears to Lear, 59 CALIF. L. REv. 873, 875-81, 883-86, 903 (1971). In contrast, because the conduct of employees who established a competing company using the trade secrets of their former employer was found to endanger "the basic decency of society," Kewanee Oil Co. v. Bicron Corp., 416 U.S. 470, 485-87 (1974), that conduct threatened vital interests and was therefore not immunized from state prohibitions. Id. at 493 .

149. 314 U.S. 33 (1941).

150. Id. at $36-37$. 
Safety ${ }^{151}$ added a new feature. This law allowed a judgment creditor to authorize issuance of a driver's license to the bankrupt tortfeasor before the tortfeasor proved financial responsibility. It could be argued that this new feature did no more than give the creditor a bargaining weapon to induce partial payment of debts discharged in bankruptcy and thus to deny effect to national bankruptcy law. ${ }^{152}$ But the Court still relied on Reitz and upheld the state law as a safety measure. Not until 1971 did Perez $v$. Campbell ${ }^{153}$ invalidate such a law to the extent that it enabled creditors to hinder debtors from making the fresh start sought by national bankruptcy law. ${ }^{154}$

\section{Determination of the Breadth of the Preemption Ruling}

Once it has determined that state regulation substantially hinders conduct necessary to a national objective, a court must decide whether to enunciate a narrow or broad rule of preemption. Many preemption cases produce holdings limited to the particular state regulation in question. However in some cases, involving air commerce at proprietary airports ${ }^{155}$ and labor-management relations, ${ }^{156}$ four features of the subject matter ${ }^{15 \pi}$ being regulated combined to create a need for the preemption of a whole category of state or local law. First, the national statute has the express and central purpose of fostering a particular relationship. Second, the statute organizes an adversarial agency decisionmaking process that ensures protection from unrea-

151. 369 U.S. 163 (1962).

152. Id. at 181.82 (Warren, C.J., dissenting).

153. 402 U.S. 637 (1971).

154. Id. at 614-49, 653-54.

155. See City of Burbank v. Lockheed Air Terminal, Inc., 411 U.S. 624 (1973) (protecting FAA efforts to foster air commerce among states). Burbank involved a municipal ordinance that threatened the safety of air travelers, id. at 639 , rather than protecting vital interests.

156. See, e.g., San Diego Bldg. Trades Council v. Garmon, 359 U.S. 236 (1959) (protecting NLRB efforts to foster relations between companies and unions). The labor preemption cases have not deprived states of authority to protect vital interests, such as public safety. See pp. 381-82 supra.

157. The Court's examination of "subject" or "subject matter" appears to be an attempt to consider the practical problems of implementing a federal statute regulating a particular relationship, and to decide whether that relationship must be wholly immunized from state and local regulation in order to achieve national statutory objectives. San Diego Bldg. Trades Council v: Garmon, 359 U.S. 236, 241-44 (1959), in which the Court discussed the need for wholesale exclusion of state authority, has accordingly been cited as involving a "subject demanding exclusive federal regulation." Florida Lime \& Avocado Growers, Inc. v. Paul, 373 U.S. 132, 143-44 (1963); see City of Burbank v. Lockheed Air Terminal, Inc., 411 U.S. 624, 625 (1973) (referring to subject of regulation as guide for preemption). But cf. Note, supra note 2, at $625 \mathrm{n} .18$ (criticizing considerations of subject matter as anomalous in preemption cases). 
sonable conduct by the parties to the relationship. ${ }^{158}$ Third, states and localities have persistently demonstrated a hostility toward this relationship. Finally, there are circumstances that prevent an adequate case-by-case national response to each instance of state and local hostility. ${ }^{159}$ By adopting a broad rule of wholesale preemption under such circumstances, the Court has barred states and localities from attempting to prove that they can regulate the relationship in question reasonably, without hostility. ${ }^{160}$

In contrast to the inference of the statutory objective, the inference of the necessity for conduct and the inference of the effect of state law take place without specific congressional guidance. Arguably the Court should not engage in determining necessity and substantial hindrance. But Congress cannot always foresee how state laws will obstruct the achievement of national statutory goals. ${ }^{161}$ Courts must inquire into

158. See p. 385 \& note 140 supra (types of adversarial system).

159. City of Burbank v. Lockheed Air 'Terminal, Inc., 411 U.S. 624 (1973), is the harder case and should be examined in detail. First, a national statute declared that the fostering of commercial aviation accords with "the public convenience and necessity," 49 U.S.C. $\$ 1303$ (1970). Second, another national statute created a process by which the Environmental Protection Agency acted as an advocate, protecting against noise pollution by scrutinizing the Federal Aviation Administration's airflight schedules. 411 U.S. at 629-32, 638-39. Third, courts had repeatedly been called on to invalidate excessively restrictive municipal noise curfews for airports. See, e.g., United States r. City of New Haven, 447 F.2d 972 (2d Cir. 1971); American Airlines v. City of Audubon Park, 297 F. Supp. 207 (W.D. Ky. 1968), aff'd, 407 F.2d 1306 (6th Cir.), cert. denied, 366 U.S. 845 (1969). Fourth, the significant number of localities that could restrict airflights helped persuade the Court that the subject demanded an "exclusive system of federal regulation." 411 U.S. at 625, 627-28, 639. But see id. at 653 (Rehnquist, J., dissenting) (FAA administrator could cope with hostility case-by-case); cf. id. at 635-36 \& n.14 (decision not applicable to all airports).

160. See e.g., San Diego Bldg. Trades Council v. Garmon, 359 U.S. 236, $241-46$ (1959); Garner v. Teamsters Local 776, 346 U.S. 485, 498-99 (1953). Because it leaves no residue of state authority, a holding of "subject matter" preemption is broader in effect than in. validation on commerce clause grounds. The commerce clause allows state legislatures to retain their ability to enact laws striking a reasonable balance between federal and state interests. See Southern Pac. Co. v. Arizona ex rel. Sullivan, 325 U.S. 761, 775-78 (1945); Dowling, Interstate Commerce and State Pou'er, 27 VA. L. REv. 1, 21-27 (1940). Moreover, holdings on commerce clause grounds can be overruled by Congress, G. Gunther, CasES axd Materings on Constitction.al Law 367.71 (9th ed. 1975), and thus are no more permanent than a premption ruling. But see Douglas v. Seacoast Prods., Inc., 431 U.S. 265,272 \& n.6 (197)) (preemption is statutory ground, addressed first because it can be congiessionally overruled). The greater breadth and equal permanence of preemption holdings justify the Court's occasional refusal to rest on preemption grounds rather than commerce clause grounds. See, e.g., Florida Lime \& Arocado Growers, Inc. v. Paul, 373 U.S. 132, 152, 156 (1963) (finding no premption; remanding on commerce clause issue); Southern Pac. Co. v. Arizona ex rel. Sullivan, 325 U.S. 761, 764-66, 775.78 (1945) (finding no precmption; insalidating law on commerce clause grounds). But see Note, supra note 70, at 225 (adrocating reliance on premption grounds).

161. See San Diego Bldg. Trades Council v. Garmon, 359 U.S. 236, 240 (1959) (many preemption problems "probably could not have been, at all events were not, forescen bv the Congress"). See also Frankfurtcr, supra note 121, at 538-39 (author of Garmon stressing need to achicve purpose of national statutes). 
these questions in order to give full effect to national statutes. Yet preempting every state law that somehow hinders choices among nationally unrestricted opportunities or performance of national duties could mean "setting aside great numbers of state statutes to satisfy a congressional purpose which would only be the product of this Court's imagination." 102 Therefore the Court has attempted "to reconcile "the operation of both statutory schemes with one another rather than holding one completely ousted." "163 The Court will preempt state law only to the extent "necessary to the furtherance of congressional aims and objectives." 164

\section{Conclusion}

State laws protecting vital state interests are generally preserved by a heavy presumption against preemption. These laws have been preempted only in cases involving express preemption and prohibition of dutiful conduct, and in very rare cases of hindrance of national policy. Even state attempts at territorial protection of less-than-vital interests have received considerable protection. In a large number of cases national and state governments have been allowed to work together to protect people inside state borders. Some of the credit for this protection must go to the Supreme Court, which in preemption cases has attempted to ensure that both governments could perform their fundamental functions. ${ }^{165}$

162. California v. Zook, 336 U.S. 725, 732-33 (1949); see notes 79 \& 121 supra (reasons for refusing to find preemption when congressional purpose is unclear).

163. Merrill Lynch, Pierce, Fenner \& Smith v. Ware, 414 U.S. 117, 127 (1973) (quoting Silver v. New York Stock Exch., 373 U.S. 341, 357 (1963)).

164. Id. at 126-27.

165. See note 115 supra. See generally Michelman, States' Rights and States' Roles: Permutations of "Sovereignty" in National League of Cities v. Usery, 86 Yale L.J. 1165, 1172-74, 1180 (1977); Tribe, Unraveling National League of Cities: The New Federalism and Affirmative Rights to Essential Government Services, 90 HARv. L. Rev. 1065, 1172-74, 1180 (1977). 